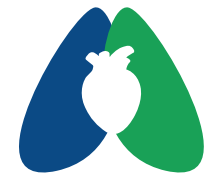

ASSOBRAFIR

C I Ê N C I A

\title{
Titration of positive end-expiratory pressure with electrical impedance tomography in pediatrics
}

\author{
Titulação da pressão positiva expiratória final com tomografia de \\ impedância elétrica na pediatria
}

Elaine Campos de Carvalho ${ }^{1}$ (D); Lorena Carla Mendes de Azevedo ${ }^{1}$ (D); Mary Lucy Ferraz Maia Fiuza de Mello² (1); Emmerson Carlos Franco de Farias ${ }^{2}$ (1); Susan Carolina Diniz de Sales ${ }^{2}$ (1); Maria de Nazaré Gomes Mesquita² (1); Guilherme Euzébio Lemes² (1); Letícia de Barros Rocha ${ }^{1}$ (D); Larissa Salgado de Oliveira Rocha ${ }^{3}$ (1); Paulo Eduardo Santos Avila ${ }^{4}$ (1); Rodrigo Santiago Barbosa Rocha ${ }^{* *}$ (1)

\begin{abstract}
Background: Electrical impedance tomography (EIT) is widely used in the practice of patients with respiratory distress syndrome (ARDS), but little is known about the determination of adequate positive end-expiratory pressure (PEEP) in the pediatric intensive care unit. Aim: Evaluating the effects of titration of PEEP with EIT after alveolar recruitment in children with ARDS on ventilatory variables and blood gas analysis. Methods: This is a longitudinal analytical study carried out in the pediatric intensive care unit. The study included 5 patients diagnosed with ARDS, aged between 6 and 11 years and had an indication for alveolar recruitment maneuver (RM). The EIT belt was posicionated around the sternum and the ventilatory variables were collected (compliance, regional ventilation, driving pressure, alveolar overdistension, alveolar collapse and PEEP titration) and blood gas analysis. The RM was performed in steps, then PEEP titration was performed with the help of the EIT. Results: There was a significant improvement in the ventilatory variables and blood gas analysis of the participants after PEEP titration. The parameters that most changed the pre- and posttitration values were pulmonary compliance $(p<0.05)$, alveolar overdistension $(p<0.05)$, partial pressure of carbon dioxide $(p<0.01)$, blood pressure of oxygen and arterial oxygen saturation $(p<0.05)$. Conclusion: Titration of PEEP with the aid of EIT is safety, improving ventilation and basic acid balance in children with ARDS.
\end{abstract}

Keywords: Positive-Pressure Respiration; Ventilator-Induced Lung Injury; Respiratory Distress Syndrome.

'Universidade do Estado do Pará (UEPA), Belém, PA, Brasil

Fundação Santa Casa de Misericórdia do Pará, Belém, PA, Brasil

${ }^{3}$ Centro Universitário do Estado do Pará (CESUPA), Belém, PA, Brasil ${ }^{4}$ Universidade Federal do Pará, Belém (UFPA), Belém, PA, Brasil

How to cite: Carvalho EC, Azevedo LCM Mello MLFMF, Farias ECF, Sales SCD, Mesquita MNG, et al. Titration of positive end-expiratory pressure with electrical impedance tomography in pediatrics. ASSOBRAFIR Ciênc. 2022;13:e44239. https:// doi.org/10.47066/2177-9333.AC.2020.0042

Submitted on: July 30, 2021

Accepted on: December 21, 2021

Study carried out at: Fundação Santa Casa de Misericórdia do Pará, Belém, PA, Brasil. Ethical approval: CAAE

78745217.8.0000.5171 from Fundação Santa Casa de Misericórdia do Pará, n².383.361.

*Corresponding author: Rodrigo Santiago Barbosa Rocha.

Email: rodrigo.santiago.rocha@uepa.br

\section{Resumo}

Introdução: A tomografia de impedância elétrica (TIE) é uma ferramenta muito utilizada na prática de pacientes com síndrome do desconforto respiratório, mas pouco estudada na determinação da pressão expiratória positiva final (PEEP) adequada na unidade de terapia intensiva pediátrica. Objetivo: Avaliar os efeitos da titulação da PEEP com TIE após recrutamento alveolar em crianças com síndrome do desconforto respiratório nas variáveis ventilatórias e gasometria. Métodos: Estudo analítico longitudinal realizado em Unidade de Terapia Intensiva Pediátrica. Participaram do estudo 5 pacientes com diagnóstico de síndrome do desconforto respiratório, com idades entre 6 a 11 anos e com indicação de manobra de recrutamento alveolar. A cinta do TIE foi fixada na altura do esterno e as variáveis ventilatórias coletadas (complacência, ventilação regional, driving pressure, hiperdistensão alveolar, colapso alveolar e titulação da PEEP) e gasometria arterial. A manobra de recrutamento foi realizada em degraus e a titulação da PEEP com auxílio da TIE. Resultados: Houve melhora significativa nas variáveis ventilatórias e gasométricas dos participantes após a titulação da PEEP. Os valores que tiveram maior alteração pré e pós titulação foram a complacência pulmonar ( $p<0,05)$, hiperdistensão alveolar $(p<0,05)$, pressão arterial de gás carbônico $(p<0,01)$, pressão arterial de oxigênio e saturação arterial de oxigênio $(p<0,05)$. Conclusão: A titulação da PEEP com auxílio da TIE é segura, melhorando a ventilação e o equilíbrio ácido básico em crianças com síndrome do desconforto respiratório.

Palavras-chave: Respiração com Pressão Positiva; Lesão Pulmonar Induzida por Ventilação Mecânica; Síndrome do Desconforto Respiratório. 


\section{INTRODUCTION}

Acute Respiratory Distress Syndrome (ARDS) affects 45.000 children annually in developed countries, with mortality of around $30 \%$, characterized by diffuse alveolar, epithelial and endothelial damage, as well as edema rich in interstitial and alveolar proteins, inflammatory cell infiltration, atelectasis, capillary thrombosis, neovascularization and pulmonary fibrosis. Clinically, it is defined by acute hypoxemia and bilateral pulmonary infiltrates, in the absence of congestive heart failure ${ }^{1,2}$. This process leads to alveolar collapse and abnormality in gas exchange, with reduced lung compliance and hypoxemia, characterizing respiratory failure ${ }^{3}$.

The recruitment maneuver (RM) has been shown as an essential clinical treatment in ARDS, with the aim of reversing the collapse of lung tissue through an intermittent and short-lived increase in airway pressure that can improve oxygenation ${ }^{4}$. After performing the $\mathrm{RM}$, it is necessary to titrate the positive end-expiratory pressure (PEEP) to prevent recruited alveoli from becoming over-distended or collapsed. A tool that can be used for this purpose is the analysis of ventilation offered by electrical impedance tomography (EIT) which among the applicabilities has a tool that allows the choice of the ideal PEEP after RM. In addition, EIT can be used to calculate regional compliance during PEEP titration and to distinguish between different non-recruited and recruited lung regions ${ }^{5}$.

Protective mechanical ventilation strategies and PEEP titration can improve oxygenation through RM, in addition to being safe for pediatric patients with acute lung injury and ARDS ${ }^{6,7}$.

The bedside EIT is an important instrument for the alveolar recruitment maneuver as it allows the choice of the appropriate PEEP value by determining the maximum recruitment value through the identification of compliance, collapse and overdistension values. Therefore, the PEEP titration tool of this equipment determines the appropriate value that should be used ${ }^{8}$.

In this scenario, it is essential that research be directed to this topic because there is a lack of studies that involve alveolar recruitment in children with ARDS; furthermore, no studies have been found in the literature that demonstrate the benefit of EIT in titrating PEEP in this population. Thus, the objective of the study was to verify the use of EIT for PEEP titration after alveolar recruitment in children with acute respiratory distress syndrome on ventilatory variables and blood gas analysis.

\section{METHODS}

Study design

A quantitative and analytical clinical longitudinal trial was carried out at the pediatric intensive care unit, between December 2017 and October 2019. The study was approved by the research ethics committee, CAAE 78745217.8.0000.5171 from Fundação Santa Casa de Misericórdia do Pará, $n^{\circ}$ 2.383.361. The clinical trial was registered with the opinion NCT03768921, available at https://www.clinicaltrials.gov. The free and informed consent form was signed by all legal guardians.

\section{Inclusion}

The sample calculation was performed using the GraphPad StatMate application, version 1.01, with a significance of $5 \%$ and a test power of $32 \%$, and the inclusion of 5 children with respiratory distress syndrome and indication of alveolar recruitment maneuver was determined.

Volunteers diagnosed with ARDS, aged between 6 and 11 years, both genders and any ethnicity, who were intubated and had an indication for alveolar recruitment maneuver were included in the study. The criteria for performing alveolar recruitment maneuver were severe hypoxemia, with $\mathrm{PaO}_{2}$ below $60 \mathrm{cmH}_{2} \mathrm{O}$, hypercapnia with $\mathrm{PaCO}_{2}$ above $60 \mathrm{cmH}_{2} \mathrm{O}$.

Volunteers who presented with another type of comorbidity or clinical condition that did not allow the performance of an alveolar recruitment maneuver such as severe acute circulatory failure, severe arterial hypotension, cardiac arrhythmia, pneumothorax or pneumatoceles were excluded from the study and/ or who was responsible for the minor did not agree to participate in the study.

\section{Procedures}

The equipment used in this research was the Timpel ${ }^{\circledR}$ Electric Impedance Tomography monitor to measure ventilatory variables (static and regional compliance, regional ventilation, driving pressure, alveolar overdistension, alveolar collapse and PEEP titration) and the DIXTAL monitor ${ }^{\circledR}$ to measure hemodynamic variables (blood pressure and oxygen pulse saturation).

The data collection process was carried out in two stages. The first stage took place before the start of the alveolar recruitment maneuver, where the minor was sedated and curarized by the medical team, in order to avoid interferences in the alveolar recruitment protocol. After that, an EIT belt posicionated around the chest at the height of the sternum body. Then the flow sensor of the ventilatory mechanics was coupled between the intubated tube of the child who was intubated and the reference sensor on the right flank of the patient's abdomen. The EIT was turned on and all the electrodes were observed to see if they were attached to the patient's chest. At this moment, the first ventilatory variables of the study were collected.

The second stage started with the alveolar RM based on the modified study ${ }^{8}$, PEEP reached up to $20 \mathrm{cmH}_{2} \mathrm{O}$ and the recruitment was carried out progressively, the 
pressure variation was maintained at $15 \mathrm{cmH}_{2} \mathrm{O}$ and the increase in PEEP occurred in a progressive manner at $1 \mathrm{cmH}_{2} \mathrm{O}$ every 2 minutes, with a respiratory rate fixed at 15 breaths per minute and the ventilation mode in Pressure-Controlled Ventilation (PCV). RM was performed on the iX5 mechanical ventilator (Carefusion/ Intermed, Cotia, Brazil).
After the alveolar RM, titration or determination of the ideal PEEP was performed, gradually reducing the PEEP by $1 \mathrm{cmH}_{2} \mathrm{O}$ every 2 minutes and the variables after checking the alveolar recruitment and maintenance of PEEP at the point where the patient had better alveolar recruitment, that is, with less points of collapse and alveolar overdistension as shown in Figure 1, with a maximum allowed overdistension of $5 \%$.

\section{PEEP step: 1}

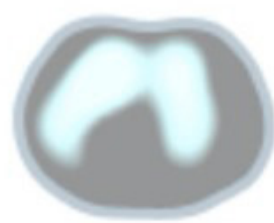

Overdistension

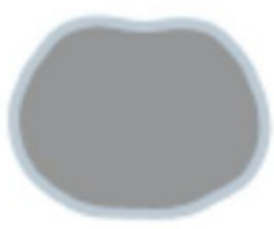

Collapse

Complacency
$20.9 \mathrm{cmH}_{2} \mathrm{O}$

$43.7 \%$

$0.0 \%$

$10.5 \mathrm{~mL} / \mathrm{cmH}_{2} \mathrm{O}$

\section{Cumulative collapse}

\section{PEEP step: 2}

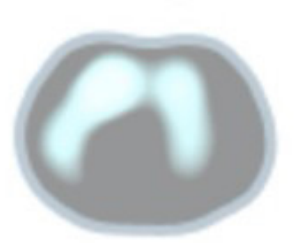

Overdistension

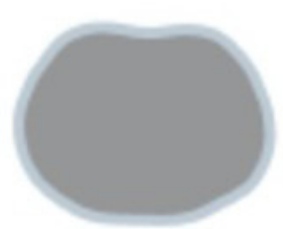

Cumulative collapse

\section{IPEEP $\quad 20.0 \mathrm{cmH}_{2} \mathrm{O}$ \\ Overdistension $33.8 \%$ \\ Collapse \\ Complacency}

\section{$11.1 \mathrm{~mL} / \mathrm{cmH}_{2} \mathrm{O}$}

\section{PEEP step: 3}

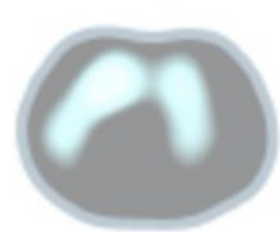

Overdistension

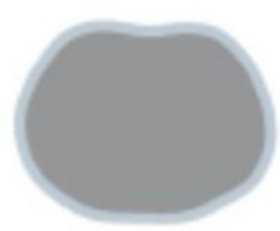

Cumulative collapse

\section{PEEP step: 4}

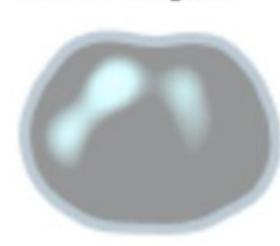

Overdistension

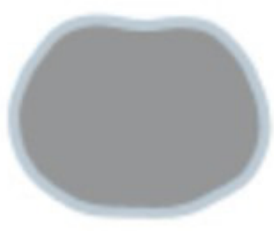

Cumulative collapse
$19.0 \mathrm{cmH}_{2} \mathrm{O}$ $30.5 \%$

Overdistension

Collapse

$0.2 \%$

Complacency $11.4 \mathrm{~mL} / \mathrm{cmH}_{2} \mathrm{O}$

\section{PEEP step: 5}

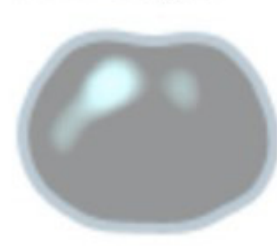

Overdistension

\section{iPEEP \\ Overdistension \\ Collapse}

Complacency
$18.0 \mathrm{cmH}_{2} \mathrm{O}$

$22.0 \%$

$0.3 \%$

Figure 1. Step-by-step representation of PEEP titration in one of the patients. 
The study participants' ventilatory and blood gas analysis variables were checked before and 2 hours after the alveolar recruitment maneuver to verify its effectiveness.

\section{Statistical analysis}

Statistical analysis was performed using the Bioestat 5.2 program (Mirauá Institute, Tefé, Brazil). For the analysis of data normality, the Shapiro-Wilk test was used, as all variables shown parametric profile Student'sT test was used to analyze the data variance as significance level $p$ $<0.05$.

\section{RESULTS}

In the period between December 2017 and October 2018, eight patients met the inclusion criteria of the study, but 3 of them were excluded for presenting hemodynamic instability, with a reduction of $20 \%$ or more in the arterial blood pressure, that did not allow the PEEP titration. From the 5 included patients, four were female and one male, with a mean age of $8.3( \pm 2.5)$ years and an average hospital stay before PEEP titration of 5 ( \pm 3.5$)$ days. Table 1 shows the data regarding the characterization of the sample.

There was a significant improvement in the ventilatory and blood gas analysis variables of the research participants after PEEP titration as can be seen in Table 2 . The parameters that most changed their values before and after PEEP titration were pulmonary compliance (pre average of $9.5 \mathrm{~mL} / \mathrm{cmH}_{2} \mathrm{O}$ and post average of $17.5 \mathrm{~mL} / \mathrm{cmH}_{2} \mathrm{O}$ ), alveolar overdistention (pre average of $39.5 \%$ and post average of $0 \%$ ), partial pressure of carbon dioxide (pre average of $88 \mathrm{mmHg}$ and post average of $52 \mathrm{mmHg}$ ) and arterial oxygen saturation (pre average of $73 \%$ and post average of $92 \%$ ).

Table 1. Sapmle characterization.

\begin{tabular}{cc}
\hline Characteristics & $(\mathrm{n}=5)$ \\
\hline Age (years) & $8.3 \pm 2.5$ \\
Male $(\mathrm{n})$ & $1(20 \%)$ \\
Female $(\mathrm{n})$ & $4(80 \%)$ \\
Length of hospitalization before titration \\
$\quad$ (days) \\
$\begin{array}{c}\text { Outcome (n) } \\
\text { Hospital discharge }\end{array}$ \\
Death after 96 hours since titration \\
Length of hospital stay after titration (days) \\
Cause of hospitalization \\
Community-Acquired Pneumonia \\
Medullary aplasia
\end{tabular}

Figure 1 and Figure 2 shows the PEEP titration process with a gradual reduction of $1 \mathrm{cmH}_{2} \mathrm{O}$ each 2 minutes. It is possible to observe large areas of alveolar distention represented by the white images that appear with PEEP up to $16 \mathrm{cmH}_{2} \mathrm{O}$ and from this point blue dots appear that represent areas of alveolar collapse.

Two out of five patients evaluated died after 96 hours of titration due to complications from sepsis and three progressed to hospital discharge. The average length of hospital stay after PEEP titration was $21.2 \pm 10.5$ days.

\section{DISCUSSION}

The main findings of this study suggest that the use of EIT during the alveolar RM is important for finding the ideal PEEP value (PEEP titration). This titration favored the improvement of ventilatory parameters and blood gas analysis in children with acute respiratory distress syndrome; it is also safe to perform the alveolar RM with the monitoring of EIT, given the real-time reading of the ventilatory variables in the critical pediatric patient. The use of the PEEP titration tool available in the EIT and make possible the assessment of compliance, hyperdistension zones and alveolar collapse, allowing, through the crossing of this information, the determination of the ideal PEEP value for each patient in real time and in a reliable way.

The use of EIT facilitates the titration of PEEP as it allows visualization and quantification in real time of the regional distribution of ventilation, in addition, it is an imaging technique that can be performed at the bedside in real time, non-invasively and free of radiation which favors its application in the pediatric population ${ }^{8,9}$.

In the practice of pediatric intensive care, the use of EIT has been shown to be a very promising technique for noninvasive monitoring of pulmonary ventilation and

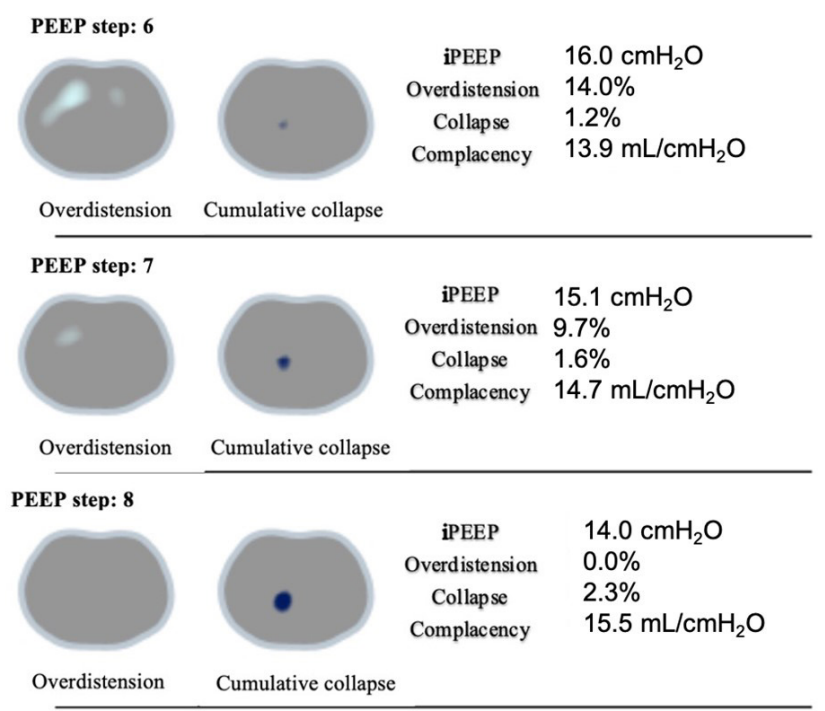

Figure 2. Representation of the PEEP titration step by step in one of the patients (continued). 
Table 2. Ventilatory and blood gas analysis variables before and after PEEP titration.

\begin{tabular}{|c|c|c|c|c|}
\hline Variables & Pre & Post & $\%$ pre & $\mathrm{p}$ \\
\hline Compliance $\left(\mathrm{mL} / \mathrm{cmH}_{2} \mathrm{O}\right)$ & $9.5 \pm 1.2$ & $17.5 \pm 2.2$ & $184.7 \%$ & $<.05$ \\
\hline Overdistension (\%) & $39.5 \pm 10.2$ & $0.2 \pm 3.9$ & & $<.05$ \\
\hline Alveolar collapse (\%) & $0.8 \pm 3.9$ & $2.3 \pm 3.4$ & & .3 \\
\hline Driving pressure $\left(\mathrm{cmH}_{2} \mathrm{O}\right)$ & $17.6 \pm 1.2$ & $12.4 \pm 2.1$ & & $<.05$ \\
\hline Tidal volume $(\mathrm{mL})$ & $186 \pm 58.1$ & $258 \pm 25.4$ & & $<.05$ \\
\hline Anteroposterior Relationship (\%) & $65 / 35$ & $59 / 41$ & & $<.01$ \\
\hline Right/Left Ratio (\%) & $44 / 55$ & $57 / 43$ & & $<.05$ \\
\hline $\mathrm{pH}$ & $7.1 \pm 1.1$ & $7.25 \pm 0.7$ & & $<.05$ \\
\hline $\mathrm{PaCO}_{2}$ & $88 \pm 35.1$ & $52 \pm 15,9$ & & $<.01$ \\
\hline $\mathrm{HCO}_{3}$ & $15 \pm 10.3$ & $20 \pm 3,4$ & & .09 \\
\hline $\mathrm{PaO}_{2}$ & $65 \pm 5.3$ & $88 \pm 10.4$ & & $<.05$ \\
\hline $\mathrm{SaO}_{2}$ & $73 \pm 15.3$ & $92 \pm 10.2$ & & $<.05$ \\
\hline Ol & $37.1 \pm 10.5$ & $17.3 \pm 8.9$ & & $<.05$ \\
\hline PEEP Value & $6.9 \pm 2.3$ & $8.3 \pm 6.7$ & & .09 \\
\hline
\end{tabular}

pH: Potential for hydrogen; PaCO2: Partial pressure of carbon dioxide; HCO3: Bicarbonate; PaO2: Oxygen partial pressure; SaO2: Arterial oxygen saturation; OI: oxygenation index.

perfusion, being easy to apply and interpret, allowing continuous monitoring of pulmonary mechanical properties for long periods ${ }^{10}$, however great part of the studies found in the literature were carried out in the adult population, a fact that may reflect in the results when compared to the use in children. Since children have lower elastic pulmonary retraction strength and relaxation volume, which can predispose to airway collapse, thus making monitoring of pediatric patient ventilation extremely important ${ }^{11}$.

In the present study, the evaluated parameters considered most important were driving pressure, static pulmonary compliance, regional ventilation, collapse and alveolar overdistension. In relation to these parameters, a reduction in driving pressure was observed, which is beneficial for patients as according to a systematic review and meta-analysis the high value of driving pressure is associated with a high mortality rate in patients under mechanical ventilation with ARDS ${ }^{12}$.

There was also an increase in static pulmonary compliance which may be related to a reduction in mortality since it is necessary to have a lower pressure value used in the airway to ventilate the patient, in this case there is less lung damage resulting from invasive mechanical ventilation ${ }^{13}$.

Improvement in regional ventilation was also observed in the research participants, corroborating a case study in which an 11-year-old girl diagnosed with acute respiratory distress syndrome also demonstrated a significant improvement in regional ventilation after the alveolar recruitment maneuver ${ }^{14}$. Another factor found in this study was the reduction of alveolar overdistension, which according to a study by Sahetya et al. ${ }^{15}$ is related to a high risk of lung injury.

Regarding the outcome and clinical evolution of children with ARDS undergoing the alveolar recruitment maneuver, two children died from complications resulting from sepsis and three evolved with improved clinical status and hospital discharge, demonstrating a $40 \%$ mortality rate. These findings differ slightly from a systematic review and meta-analysis, in which studies published from 1993 to 2015 on the mortality of children with ARDS were evaluated, in which they pointed to a mortality rate of $24 \%{ }^{16}$, and from another study that demonstrated the prognosis of children with sepsis, which is responsible for $10 \%$ of deaths ${ }^{17}$.

The safety of alveolar recruitment maneuvers is widely debated in the literature ${ }^{18,19}$, this study also reinforces the safety of the technique, even more when guided by the use of EIT, since none of the children who participated in the study had any type of complication resulting from the alveolar recruitment maneuver. What was observed in the study was an improvement in pulmonary ventilation and basic-acid balance.

The future of ventilatory monitoring of critical pediatric patients should occur in tools that form images of the rib cage at the bedside, facilitating diagnosis and allowing the understanding of the pathogenesis and pathophysiology of a series of diseases ${ }^{20}$. 


\section{Limitations}

The study has some limitations such as the small sample size, due to the reduced number of hospitalizations in the data collection period. There was also no standardization of the underlying cause of hospitalization for inclusion in the study, however all patients included had attested respiratory distress syndrome. Another limitation is due to the scarcity of literature related to the subject aimed at the pediatric public which hindered the comparative analysis of the results found with existing results, as it is known that there are considerable anatomo-physiological differences between adults and children that prevent a reliable comparison between the children. results found in this research with other similar studies carried out in adults.

\section{CONCLUSION}

Given the above, it is concluded that the use of the PEEP titration with electrical impedance tomography in patients with respiratory distress syndrome was safe and effective for the improvement of ventilatory and blood gas analysis variables in children with acute respiratory distress syndrome.

\section{FUNDING}

Nothing to declare.

\section{CONFLICT OF INTEREST}

Nothing to declare.

\section{REFERENCES}

1. García-Laorden MI, Lorente JA, Flores C, Slutsky AS, Villar J. Biomarkers for the acute respiratory distress syndrome: how to make the diagnosis more precise. Ann Transl Med. 2017;5(14):283. http://dx.doi.org/10.21037/atm.2017.06.49. PMid:28828358.

2. Yehya N, Thomas NJ. Disassociating lung mechanics and oxygenation in pediatric acute respiratory distress syndrome. Crit Care Med. 2017;45(7):1232-9. http://dx.doi. org/10.1097/CCM.0000000000002406. PMid:28350644.

3. Aleksandrovich US, Pechueva OA, Pshenisnov KV. Alveolar recruitment maneuvers oxygenation effects in newborns with infant respiratory distress syndrome. Anesteziol Reanimatol. 2013;(1):21-5. PMid:23808248.

4. Chung FT, Lee CS, Lin SM, Kuo CH, Wang TY, Fang YF, et al. Alveolar recruitment maneuver attenuates extravascular lung water in acute respiratory distress syndrome. Medicine. 2017;96(30):e7627. http://dx.doi.org/10.1097/ MD.0000000000007627. PMid:28746224.

5. Ball L, Vercesi V, Costantino F, Chandrapatham K, Pelosi P. Lung imaging: how to get better look inside the lung. Ann Transl Med. 2017;5(14):294. http://dx.doi.org/10.21037/ atm.2017.07.20. PMid:28828369.

6. Boriosi JP, Sapru A, Hanson JH, Asselin J, Gildengorin G, Newman $V$, et al. Efficacy and safety of lung recruitment in pediatric patients with acute lung injury. Pediatr Crit Care Med. 2011;12(4):431-6. http://dx.doi.org/10.1097/ PCC.0b013e3181fe329d. PMid:21057351.

7. Duff JP, Rosychuk RJ, Joffe AR. The safety and efficacy of sustained inflations as a lung recruitment maneuver in pediatric intensive care unit patients. Intensive Care Med. 2007;33(10):1778-86. http://dx.doi.org/10.1007/s00134-0070764-2. PMid:17607560.

8. Frerichs I, Becher T, Weiler N. Electrical impedance tomography imaging of the cardiopulmonary system. Curr Opin Crit Care. 2014;20(3):323-32. http://dx.doi.org/10.1097/ MCC.0000000000000088. PMid:24739268.

9. Ngo C, Dippel F, Tenbrock K, Leonhardt S, Lehmann S. Flow-volume loops measured with electrical impedance tomography in pediatric patients with asthma. Pediatr Pulmonol. 2018;53(5):636-44. http://dx.doi.org/10.1002/ ppul.23962. PMid:29405616.

10. Durlak W, Kwinta P. Role of electrical impedance tomography in clinical practice in pediatric respiratory medicine. ISRN Pediatr. 2013;2013:529038. http://dx.doi. org/10.1155/2013/529038. PMid:24455294.

11. Mazzoni MB, Perri A, Plebani AM, Ferrari S, Amelio G, Rocchi A, et al. Electrical impedance tomography in children with community acquired pneumonia: preliminary data. Respir Med. 2017;130:9-12. http://dx.doi.org/10.1016/j. rmed.2017.07.001. PMid:29206639.

12. Aoyama H, Pettenuzzo T, Aoyama K, Pinto R, Englesakis $M$, Fan E. Association of driving pressure with mortality among ventilated patients with acute respiratory distress syndrome: a systematic review and meta-analysis. Crit Care Med. 2018;46(2):300-6. http://dx.doi.org/10.1097/ CCM.0000000000002838. PMid:29135500.

13. Hess DR. Recruitment maneuvers and PEEP titration. Respir Care. 2015;60(11):1688-704. http://dx.doi.org/10.4187/ respcare.04409. PMid:26493593.

14. Dmytrowich J, Holt T, Schmid K, Hansen G. Mechanical ventilation guided by electrical impedance tomography in pediatric acute respiratory distress syndrome. J Clin Monit Comput. 2018;32(3):503-7. http://dx.doi.org/10.1007/ s10877-017-0048-5. PMid:28730574.

15. Sahetya SK, Goligher EC, Brower RG. Fifty years of research in ARDS. Setting positive end-expiratory pressure in acute respiratory distress syndrome. Am J Respir Crit Care Med. 2017;195(11):1429-38. http://dx.doi.org/10.1164/ rccm.201610-2035Cl. PMid:28146639.

16. Wong JJ, Jit M, Sultana R, Mok YH, Yeo JG, Koh JWJC, et al. Mortality in pediatric acute respiratory distress syndrome: a systematic review and meta-analysis. J Intensive Care Med. 2019;34(7):563-71. http://dx.doi. org/10.1177/0885066617705109. PMid:28460591.

17. Plunkett A, Tong J. Sepsis in children. BMJ. 2015;350:h3017. http://dx.doi.org/10.1136/bmj.h3017. PMid:26060188.

18. Amorim EF, Guimaraes VA, Carmona F, Carlotti AP, Manso $\mathrm{PH}$, Ferreira CA, et al. Alveolar recruitment manoeuvre is safe in children prone to pulmonary hypertensive crises following open heart surgery: a pilot study. Interact Cardiovasc Thorac Surg. 2014;18(5):602-6. http://dx.doi.org/10.1093/icvts/ ivt484. PMid:24480822.

19. Lista G, Castoldi F, Cavigioli F, Bianchi S, Fontana P. Alveolar recruitment in the delivery room. J Matern Fetal Neonatal Med. 2012;25(Suppl 1):39-40. http://dx.doi.org/10.3109/14 767058.2012.663164. PMid:22313342.

20. Pesenti A, Musch G, Lichtenstein D, Mojoli F, Amato MBP, Cinnella $G$, et al. Imaging in acute respiratory distress syndrome. Intensive Care Med. 2016;42(5):686-98. http:// dx.doi.org/10.1007/s00134-016-4328-1. PMid:27033882. 